\title{
INTENÇÃO EMPREENDEDORA E O MERCADO DE TRABALHO EM CARAGUATATUBA
}

\section{Graziela de Faria Santos Soares ${ }^{1}$ \\ Quésia Postigo Kamimura² \\ Marcela Barbosa de Moraes ${ }^{3}$}

Resumo: Este artigo objetiva destacar os aspectos positivos da Intenção Empreendedora no mercado de trabalho no município de Caraguatatuba, e para isso utilizará de levantamento bibliográfico sobre mercado de trabalho e intensão empreendedora, bem como análise de dados secundários em relação a este mercado no município. A fonte de renda de grande parte da população é constituída por sua força de trabalho, e a força geradora de riqueza das empresas advém da mão-de-obra disponível, definindo o mercado de trabalho, onde os fatores mais discutidos é a qualificação de quem procura o trabalho, a falta de vagas para a atuação e o novo arcabouço desta relação proveniente dos cenários globalizados, que trazem novas tendências exigindo profissionais que possuam maior autonomia e promovam novos empreendimentos. Como resultado o artigo apresenta que o levantamento da intenção empreendedora no município de Caraguatatuba, pode ser um primeiro passo para repensar as políticas de fomento, as ações de conscientização e conteúdos abordados pelos órgãos de apoio ao empreendedorismo local.

Palavras-chave: Desenvolvimento; Mercado de trabalho; Intenção empreendedora.

\footnotetext{
1 Aluna do programa de Mestrado Acadêmico em Planejamento e Desenvolvimento Regional/Universidade de Taubaté - UNITAU, Brasil. E-mail: grazicaragua@gmail.com.

2 Professora Dra. do programa de Mestrado Acadêmico em Planejamento e Desenvolvimento Regional/Universidade de Taubaté - UNITAU, Brasil. E-mail: qkamimura@gmail.com.

3 Professora Dra.do programa de Mestrado Acadêmico em Planejamento e Desenvolvimento Regional/Universidade de Taubaté - UNITAU, Brasil. E-mail: marcelabmoraes@gmail.com.
} 